\title{
Impact of Psychotherapy on School Performance in School Going Adolescent
}

\author{
Prerna Panwar', Nutan Singh ${ }^{2}$, Ramesh Chand $^{3}$, Ashok Kumar ${ }^{4}$ \\ ${ }^{1}$ PG, JR Department o Pediatrics, Government Medical College Haldwani, Nainital, Uttarakhand, India, ${ }^{2}$ Associate Professor Department of Pediatrics \\ ,Government Medical College Haldwani, Uttrakhand, India, ${ }^{3}$ Assistant Professor Department of Pediatrics ,Government Medical College Haldwani, Uttrakhand, \\ India.
}

\section{Abstract}

Background: Psychotherapy is the use of psychological methods particularly when based on interpersonal interaction to help a person to change behaviour and overcome emotional problems like aggression, low self-esteem, anxiety. As a part of Psychotherapy, counselling is a learning oriented process which usually occurs in an interactive relationship with the aim of helping students to learn more about him or herself. Subjects and Methods: The study was conducted in department of Paediatrics Dr Sushila Tiwari Hospital Haldwani Uttarakhand. It was a school based study and students of 9th and 10th class (13-17 years) with normal IQ were included. The result was analysed on the basis of a preformed questionnaire filled by children, teacher, parents before and after counselling and taking record of previous school performance. Result: 150 students 39 female and 111 male participated in the study.84.7\% agreed that counselling sessions were helpful to them.72\% students have shown good improvement in academic performance and 64\% have shown increment of 6 to $10 \%$ marks. Conclusion: Counselling programmes create a positive impact on the academic performances, career choices, course selection, college and career planning. This study shows that use of excessive social media and poor concentration in studies are among the major causes of poor performances.

Keywords: Psychotherapy, School Performance.

Corresponding Author: Dr Nutan Singh, Associate Professor Department of Pediatrics, Government Medical College Haldwani, Uttrakhand, India.

Email: prernapanwar55@gmail.com

Received: April 2020

Accepted:April 2020

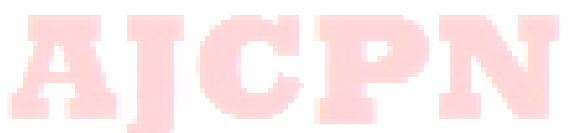

Introduction

Psychotherapy is the informed and intentional application of clinical methods and interpersonal stances derived from established psychological principles for the purpose of assisting people to modify their behaviour, cognitions, emotions and other personal characteristics in directions that the participants deem desirable. For achievement of meaningful and satisfying life individuals need two competencies the ability to form enduring relationships and capacity for productive activity .Pillars of these competencies are erected at home and school where students learn and grow intellectually, socially, emotionally and ethically thus the development of interpersonal and academic competencies, citizenship skills and moral character are considered to be primary functions of schooling. Academic success of students depends upon their school performances as well as in academic behavior. The study on poor school performances addresses current aspects of academic education, learning and behavioral problems like low self-esteem, anxiety etc and also focuses on main conditions involved in poor school performance.

\section{Subjects and Methods}

The present study was prospective observational study conducted in Sushila Tiwari Government medical college, Haldwani. The study cohort consisted of 150 school going students between 13 to 17 years. The study had been done by school visit at Haldwani city during the period of January 2018 to April 2019.

\section{Inclusion Criteria}

- Students of 9th and 10th class of both sexes.

- Normal IQ.

- Apparently healthy.

\section{Exclusion Criteria}

- Low IQ.

- Chronic illness.

- Endocrinal disorders.

- Students not willing to participate.

An informed consent was obtained from student before enrolling them for study. By analysis of preformed 
questionnaire filled by children, teacher, parents before and after counselling and the evaluation of causes was done with the help of a child psychologist. Questionnaire contain questions regarding academic difficulties and their causes, career choices, family type, living conditions, parents and teachers remarks of the improvement after psychotherapy and counselling. During psychotherapy sessions students were given proper guidance and motivation on how to deal with psychological problems which could badly impact their studies and behaviour and to develop certain problemsolving skills which to an extent help them deal with particular issues surrounding their lives and also helps them to cope with different situations they tend to face in their school life.

\section{Results}

[Table 1] showing gender distribution of the study groups. In this study as shown in table 1 , a total 150 students were chosen,111 (74\%) of which were males and $39(26 \%)$ of which were females.

\begin{tabular}{|l|l|l|}
\hline Table 1: Gender Distribution. \\
\hline & Frequency & Percent \\
\hline Male & 111 & 74 \\
\hline Female & 39 & 26 \\
\hline Total & 150 & 100 \\
\hline
\end{tabular}

[Table 2] shows distribution of causes of poor school performance.

In this study as shown in [Table 2], Excessive use of social media and poor concentration in studies were major causes of poor school performance among students.

[Table 3] shows distribution and improvement in academic score grades.

In this study as shown in Table 3, Overall improvement in academic performance of students after psychotherapy and counselling was $72 \%$ with $p$ value of $<0.001$ which was statistically significant.

[Table 4] shows increment in marks after counselling.

In this study as shown in [Table 4], 64\% students shows increment in marks of 6 to $10 \%$.

\begin{tabular}{l}
\hline Table 2: Distribution of Causes of Poor School Performance. \\
\begin{tabular}{|l|l|l|l|}
\hline S.No & Reason for Poor Performance & Frequency(n) & $\%$ \\
\hline 1 & No self study & 74 & $49.3 \%$ \\
\hline 2 & Excessive use of social media & 121 & $80.7 \%$ \\
\hline 3 & Anxiety & 7 & $4.7 \%$ \\
\hline 4 & Poor concentration & 112 & $74.7 \%$ \\
\hline 5 & Poor reading techniques & 41 & $27.3 \%$ \\
\hline 6 & Indiscipline & 27 & $18.0 \%$ \\
& (a)watching violent movies & 28 & $18.6 \%$ \\
\hline 7 & Parental separation & 37 & $24.7 \%$ \\
\hline 8 & Parent death & 19 & $12.7 \%$ \\
\hline 9 & Addiction & 1 & $0.7 \%$ \\
\hline 10 & Poor performance of close friends & 83 & $55.3 \%$ \\
\hline 11 & Change of school & 106 & $70.7 \%$ \\
\hline 12 & Low socioeconomic status & 13 & $8.7 \%$ \\
\hline 13 & Callous attitude of parents & 53 & $35.3 \%$ \\
\hline 14 & Past medical illness & 13 & $8.7 \%$ \\
\hline 15 & Poor learning and understanding & 106 & $70.7 \%$ \\
\hline 16 & Joint family & 51 & $34.0 \%$ \\
\hline 17 & Illiterate parents & 9 & $6.0 \%$ \\
\hline 18 & No goals & 95 & $63.3 \%$ \\
\hline 19 & Low school attendance & 20 & $13.3 \%$ \\
\hline 20 & Excessive friend circle & 20 & $13.3 \%$ \\
\hline
\end{tabular}
\end{tabular}

Table 3: Distribution and Improvement in Academic Score Grades.

\begin{tabular}{|c|c|c|c|c|c|c|c|c|c|}
\hline \multirow[t]{3}{*}{ S. No } & \multirow{3}{*}{$\begin{array}{l}\text { Pre } \\
\text { Counselling } \\
\text { Academic } \\
\text { Score Grade }\end{array}$} & \multirow[t]{3}{*}{ Total } & \multicolumn{5}{|c|}{ Post Counselling Academic Score Grade } & \multirow{3}{*}{$\begin{array}{l}\text { Total } \\
\text { improved } \\
\text { Students }\end{array}$} & \multirow[t]{3}{*}{ p value } \\
\hline & & & $\begin{array}{l}\mathbf{4 0 \%} \% \\
\text { (grade 1) }\end{array}$ & $\begin{array}{l}\text { 40-50\% } \\
\text { (grade 2) }\end{array}$ & $\begin{array}{l}50-60 \% \\
\text { (grade 3) }\end{array}$ & $\begin{array}{l}60-70 \% \\
\text { (grade 4) }\end{array}$ & $\begin{array}{l}>70 \% \\
\text { (grade 5) }\end{array}$ & & \\
\hline & & & $\begin{array}{l}\text { Frequency } \\
(\%)\end{array}$ & $\begin{array}{l}\text { Frequency } \\
(\%)\end{array}$ & $\begin{array}{l}\text { Frequency } \\
(\%)\end{array}$ & $\begin{array}{l}\text { Frequency } \\
(\%)\end{array}$ & $\begin{array}{l}\text { Frequency } \\
(\%)\end{array}$ & & \\
\hline 1 & $<40 \%$ (grade 1$)$ & $16(11.0 \%)$ & $3(18.8 \%)$ & $10(62.5 \%)$ & $3(18.8 \%)$ & $0(0.0)$ & $0(0.0)$ & 13 & \multirow[t]{6}{*}{$<0.001$} \\
\hline 2 & $\begin{array}{l}40-50 \% \text { (grade } \\
\text { 2) }\end{array}$ & $39(26.0 \%)$ & $0(0.0 \%)$ & $8(20.5 \%)$ & $29(74.4 \%)$ & $2(5.1 \%)$ & $0(0.0)$ & 31 & \\
\hline 3 & $\begin{array}{l}50-60 \% \text { (grade } \\
3)\end{array}$ & $61(40.6 \%)$ & $0(0.0 \%)$ & $0(0.0 \%)$ & $13(21.3 \%)$ & $47(77.0 \%)$ & $1(1.6 \%)$ & 48 & \\
\hline 4 & $\begin{array}{l}60-70 \% \text { (grade } \\
4)\end{array}$ & $24(16.0 \%)$ & $0(0.0 \%)$ & $0(0.0 \%)$ & $0(0.0)$ & $8(33.3 \%)$ & $16(66.7 \%)$ & 16 & \\
\hline \multirow[t]{2}{*}{5} & $>70 \%($ grade 5$)$ & $10(1.0 \%)$ & $0(0.0 \%)$ & $0(0.0)$ & $0(0.0)$ & $0(0.0)$ & $10(100 \%)$ & 0 & \\
\hline & Total & 150 & $3(2.0 \%)$ & $18(12.0 \%)$ & $45(30.0 \%)$ & $57(38.0 \%)$ & $27(18.3 \%)$ & $108(72 \%)$ & \\
\hline
\end{tabular}


Table 4: Increment in Marks after Counselling.

\begin{tabular}{|l|l|l|l|}
\hline S. No & Increment & Frequency(n) & \% \\
\hline 1 & $1-5 \%$ & 48 & $32.0 \%$ \\
\hline 2 & $6-10 \%$ & 96 & $64.0 \%$ \\
\hline 3 & $11-15 \%$ & 5 & $3.3 \%$ \\
\hline 4 & $>15 \%$ & 1 & $0.7 \%$ \\
\hline & Total & 150 & $100 \%$ \\
\hline
\end{tabular}

Table 5: Students Assessment of Counselling Sessions.

\begin{tabular}{|l|l|l|l|}
\hline S.NO & Student remark & Frequency & \% \\
\hline 1 & Helpful & 127 & $84.7 \%$ \\
\hline 2 & Not Helpful & 4 & $2.6 \%$ \\
\hline 3 & Not Known & 19 & $12.7 \%$ \\
\hline & Total & 150 & $100 \%$ \\
\hline
\end{tabular}

[Table 5] shows students assessment of counselling sessions. In this study as shown in [Table 5], 84.7\% students found counselling sessions helpful.

\section{Discussion}

Education is one of the most important aspects of human resource development every child should have the opportunity to achieve his/her academic potential. In recent years complaints of poor school performances and difficult learning in children have increased in doctor clinics. These complaints should be valued and appropriately assessed for their causes and making timely interventions.

The purpose of this study was to understand the causes for poor school performance amongst students and explore the impact of psychotherapy in improvement of school performance. In this study we have compared the pre and post counselling results of academic performance of students. Our study had shown that $84 \%$ students found counselling sessions to be helpful with $72 \%$ students showing an improvement in marks of which $64 \%$ students showed an increment of 6-10\% marks post counselling with the $\mathrm{p}$ value of $<0.001$ which is statistically significant. It was observed that students who attended more number of counselling sessions showed better response than those who attended less number of sessions. The findings were consistent with those mentioned by Renuka Devi M.R., Devaki P.R., et al study on the "Effect of Counselling on the Academic Performance of College Students" which revealed that $93 \%$ students found counselling sessions useful, $43 \%$ students showed increment in marks by $15-25 \%$ and $13 \%$ students showed $10-15 \%$ increment of marks. The study also found that the more than $50 \%(43+13 \%)$ of students had shown good improvement after the counselling and number of counselling sessions correlated positively with the academic performance, Nweze and Okolie et al study in Nigeria confirms guidance and counselling services are important for beneficial changes in academic performance, self-understanding and career choices.

In our study Causes for Poor School Performance were as follows

Student Related Factors: Excessive use of social media (80.7\%),Poor concentration in study $(74.7 \%)$,Poor learning and understanding (70.7\%), Change of school $(70.7 \%)$,No goals $(63.3 \%)$, Poor performance of close friends/siblings $(55.3 \%)$, No self-study $(49.3 \%)$, Poor reading techniques (27.3\%), Indiscipline (18.0\%),Excessive friend circle (13.3\%), Low school attendance (13.3\%), Past medical illness (8.7\%), Anxiety (4.7\%), Addiction (0.7\%).

Family Related Factors: Callous attitude of parents (35.3\%), Joint family (34.0\%), Parental separation $(24.7 \%)$, Parent death (12.7\%), Low socioeconomic status $(8.7 \%)$, Illiterate parents $(6.0 \%)$. Similar results have been found by Manizheh Alami et al who conducted a study on "Causes of poor school performance among Omani students" and found $76.7 \%$ Student related factors including no self-study (16.5\%), low school attendance $(15.04 \%)$, not understanding subject/finding subject difficult(6.79\%), not focusing while teacher teaches $(6.31 \%)$, playing with mobile(5.09\%) indiscipline $(0.48 \%)$, addiction $(1.96 \%)$ and other causes accountant for poor school performance among student related factors were;- coming late to the class/exam $(5.58 \%)$, laziness $(4.61 \%)$, dislike to study (4.36\%), not understanding teacher's language (3.64\%), talking in classroom $(2.91 \%)$, having problem with teacher/dislikes teacher $(2.42 \%)$, having no plan for future $(1.69 \%)$, feeling shy/feeling uncomfortable because of mixed classes $(1.45 \%)$, dislike college $(1.21 \%)$, cheating $(0.72 \%)$, spending too much time with friends $(0.48 \%)$, having exam phobia $(0.24 \%)$.Family related factors including uneducated parents and big family(80.0\%), Poor family and Divorced parents $(4.44 \%)$, parents have no idea how to treat/bring up children $6.66 \%$,permissive parents/ no discipline $2.22 \%$.

\section{Conclusion}

Through psychotherapy and counselling awareness was created among students regarding educational and career options and were given psychological and social guidance. With this study we sought to inculcate discipline among students and an improvement in academic performance was noticed .Student were benefitted in areas of learning, improved concentration and decreased usage of mobile.

\section{References}

1. Dreeben, R. On What is Learned in School. Massachusetts: Addison Wesley; 1968

2. Crow LD, Crow. Adolescent development and adjustment, McCrrew Hill Book Company, U.S;1969

3. Karande S, Kulkarni M. Poor School Performance. Ind J Pediatric 2005;72(11):961-967.

4. Gerler ER Elementary school counselling research and the classroom learning environment. Elementary school guidance and counselling 1985;20:39-48

5. Campbell LF, Norcross JC, Vasquez MJ, Kaslow NJ. Recognition of psychotherapy effectiveness. APA Resol 2013;50(1):98-101.

6. Dreeben, R. On What is Learned in School. Massachusetts: Addison Wesley; 1968.

7. Devi R., Devaki PR. The Effect of Counselling on the Academic Performance of College Students Ind J Pediatric 2013;81(10):1211-15. 


\section{Panwar et al; Impact of Psychatherapy an Schaal Perfarmance in Schaal Gaing Adalescent}

8. Nweze T, Okolie U. Effective Guidance and Counselling Programs in Secondary Schools: Issues and Roles in students Career Decision Making. J Res Methods Edu 2011;4:63-68.

9. Alami M. Causes of Poor Academic Performance among Omani
Students. Int J Soc Sci Res 2016;4(1):56-61.

10. Manzoor S, Shah H. ,Level of Attention of Secondary School Students and its relationship with their Academic performance. J Arts Humanities $2015 ; 4(5): 73-7$.

Copyright: () the author(s), 2020. It is an open-access article distributed under the terms of the Creative Commons Attribution License (CC BY 4.0), which permits authors to retain ownership of the copyright for their content, and allow anyone to download, reuse, reprint, modify, distribute and/or copy the content as long as the original authors and source are cited.

How to cite this article: Panwar P, Singh N, Chand R, Kumar A. Impact of Psychotherapy on School Performance in School Going Adolescent. Asian J. Clin. Pediatr. Neonatol. 2020;8(1):85-88.

DOI: dx.doi.org/10.47009/ajcpn.2020.8.1.20

Source of Support: Nil, Conflict of Interest: None declared. 